\title{
Pengaruh Kepuasan Komunikasi Organisasi Terhadap Kinerja Pegawai Di Sekretariat DPRD Kota Singkawang
}

\author{
Kurnia Riyantini dan Agus Triyono \\ Program Studi Ilmu Komunikasi Universitas Muhammadiyah Surakarta \\ kurniariyantini@gmail.com,agus.triyono@ums.ac.id
}

\begin{abstract}
In an effort to achieve a success, then the satisfaction of organizational communication is a very important factor, it 'caused communication satisfaction is the result of a number of processes that are internal and external.Employees is one of the most important assets who participate in helping in the achievement effortof organizational goals that is realization of the vision and mission of the organization. Therefore, good cooperation between the organization and all employees are indispensable so that common goals can be realized. This research aims to find the influence of communication organizational satisfaction to employees performance in Secretariat Legislature Singkawang city. This research uses quantitative research, the method used in this research is survey method. In this research, researcher used a questionnaire as the data collection technique. Sample in this study is all civil servants in Secretariat Legislature Singkawang city numbered as many as 35 people. Data analysis techniques used in this study is simple linear regression analysis techniques. Based on the results of simple linear regression test, obtained constant values from the regression variable employees performance that is equal 26,603 . While the regression coefficient of the variable communication organization satisfaction is positive that is equal 0,462 . This means that the variable communication organization satisfaction have a positive influence on variable employees performance that is equal 0,462. Based on t-test result, obtained $t$ value of 3,874, greater than the $t$ table value of 2,034. Therefore, it can be concluded that $H_{0}$ rejected. This mean that the amount of significant influence among the variables communication organization satisfaction to employees performance of 31,3\% while the rest $68,7 \%$ influenced by other variable.
\end{abstract}

Keywords: Communication Organization, Communication Organization Satisfaction, Employees Performance.

\begin{abstract}
Abstrak
Dalam upaya mencapai suatu keberhasilan, maka kepuasan komunikasi merupakan faktoryang sangat penting, karena kepuasan komunikasi merupakan hasil dari sejumlah proses yang bersifat internal dan eksternal. Pegawai merupakan salah satu aset terpenting yang turut serta berperan dalam upaya pencapaian tujuan organisasi, yaitu terwujudnya visi dan misi dari organisasi tersebut. Maka dari itu, diperlukan kerja sama yang baik antara organisasi dengan para pegawai, guna terwujudnya tujuan bersama. Penelitian ini bertujuan untuk menemukan pengaruh antara kepuasan komunikasi organisasi terhadap kinerja pegawai di Sekretariat DPRD Kota Singkawang. Penelitian
\end{abstract}


ini menggunakan jenis penelitian kuantitatif, metode yang digunakan dalam penelitian ini adalah metode survey. Dalam penelitian ini peneliti menggunakan Kuesioner (angket) sebagai teknik pengumpulan data. Sampel dalam penelitian ini adalah seluruh Pegawai Negeri Sipil (PNS) di Sekretariat DPRD Kota Singkawang yang berjumlah sebanyak 35 orang. Teknik analisis data yang digunakan dalam penelitian ini adalah teknik analisis regresi linear sederhana. Berdasarkan dari hasil uji regresi linear sederhana, didapat nilai konstan dari regresi variabel kinerja pegawai sebesar 26,603. Sedangkan koefisien regresi dari variabel kepuasan komunikasi organisasi bernilai positifyaitu sebesar 0,462. Hal ini berarti bahwa variabel kepuasan komunikasi organisasi mempunyai pengaruh yang positif terhadap variabel kinerja pegawai sebesar 0,462. Berdasarkan dari hasil uji t, didapat nilai $t$ sebesar 3,874 lebih besar dari nilai $t_{\text {tabel }}$ sebesar 2,034.Maka dari itu, dapat disimpulkan bahwa $H_{o}$ ditolak. Hal ini menunjukkan bahwa adanya besaran pengaruh yang signifikan antara variabel kepuasan komunikasi organisasi terhadap variabel kinerja pegawai sebesar 31,3 \% sedangkan 68,7\% sisanya dipengaruhi oleh variabel lain.

Kata Kunci: Komunikasi Organisasi, Kepuasan Komunikasi Organisasi, Kinerja Pegawai.

\section{PENDAHULUAN}

Komunikasi merupakan salah satu unsur penting yang tidak dapat dipisahkan dari kehidupan kita sebagai makhluk sosial. Karena melalui komunikasi, kita dapat bertukar pikiran dan perasaan dengan sesama, sehingga terjalin suatu hubungan yang harmonis. Setiap orang berkomunikasi dengan orang lain guna mencapai tujuan yang sama, yaitu menyampaikan pesan kepada orang lain, sehingga tercipta kesamaan makna. Begitu juga bagi organisasi, komunikasi merupakan salah satu unsur terpenting bagi kelangsungan sebuah organisasi. Selain itu, komunikasi juga merupakan alat atau sarana bagi organisasi untuk dapat saling memahami antar semua anggotanya. Dengan adanya komunikasi yang baik, suatu organisasi dapat berjalan dengan lancar dan berhasil (Manopo, 2014).

Organisasi dapat dikatakan sukses apabila hubungan komunikasi antar semua pihak internalnya terjalin harmonis. Dalam sebuah organisasi, terdapat beberapa bentuk hubungan komunikasi, yaitu komunikasi vertikal, merupakan komunikasi yang terjalin antara atasan kepada bawahan atau sebaliknya, serta komunikasi horizontal, yaitu komunikasi yang terjalin antar sesama rekan kerja. Di dalam organisasi, setiap orang memiliki tugas, fungsi serta jabatan yang berbeda. Sehingga, komunikasi yang baik antar semua pihak sangat diperlukan, guna menghindari terjadinya kesalahpahaman terhadap pesan yang disampaikan. Komunikasi yang terjalin harmonis dalam suatu organisasi akan memudahkan anggotanya untuk mengkoordinasikan setiap kegiatan keorganisasian.Maka dari itu, sebuah organisasi atau instansi sangat membutuhkan komunikasi bagi kelangsungan organisasi tersebut. Selain itu, Komunikasi organisasi juga dapat digunakan sebagai tolak ukur dari keefektifan kerja fungsional suatu organisasi. Hal ini dapat dilihat dari faktor kepuasan para pegawai terhadap segala aspek komunikasi yang terjalin dalam organisasi tersebut.

Kepuasan dalam hal ini berhubungan dengan kenyamanan seseorang terhadap suatu organisasi. Kenyamanan dalam hal ini mencakup kenyamanan dengan pesan-pesan, baik dari atasan kepada bawahan maupun sebaliknya, media yang digunakan untuk menyebarluaskan informasi, serta hubunganhubungan yang terjalin dalam organisasi (Wayne Pace \& Faules, 2013). Kepuasan juga berhubungan dengan kebutuhan seseorang akan infomasi yang cukup seputar 
pekerjaannya, informasi seputar organisasi, serta komunikasi yang harmonis baik secara vertikal maupun horizontal. Selain itu, dalam upaya untuk mencapai suatu keberhasilan, maka kepuasan komunikasi merupakan faktor yang sangat penting untuk diperhatikan. Sebab, kepuasan komunikasi merupakan hasil dari sejumlah proses yang bersifat internal dan eksternal (Kosasih \& Susanto, 2014).

Terkait pada usaha untuk mencapai keberhasilan sebuah organisasi, bukan semata-mata ditentukan oleh faktor komunikasinya saja. Para pegawai juga merupakan salah satu aset terpenting yang turut serta berperan dalam upaya pencapaian tujuan organisasi, yaitu terwujudnya visi dan misi dari organisasi tersebut. Dikarenakan sumber daya manusia merupakan salah satu faktor penting dalam sebuah organisasi, maka organisasi membutuhkan para pegawai yang berkualitas serta memiliki kinerja yang memuaskan. Maka dari itu, sebuah organisasi harus mampu mengelola sumber daya manusianya agar dapat bekerja dengan baik dan memuaskan, sehingga tujuan dari organisasi dapat terwujud (Umam, 2010).

Setiap pegawai yang menjalankan aktivitas-aktivitas dalam sebuah organisasi merupakan individu yang memiliki kebutuhan bermacam-macam, serta selalu berusaha untuk memuaskan kebutuhannya tersebut. Kepuasan terhadap kebutuhan akan membantu para pegawai dalam menjalankan setiap aktivitasnya dengan baik. Jika para pewagai merasa puas terhadap komunikasi yang terjalin dalam sebuah organisasi, diharapkan hal tersebut akan berpengaruh positif terhadap kinerja mereka.Maka dari itu, diperlukan kerja sama yang saling menguntungkan antara organisasi dengan para pegawai, guna terwujudnya tujuan bersama.

Dalam peraturan Walikota Singkawang Nomor 2 Tahun 2009 tentang Tugas Pokok, Fungsi dan Tata Kerja Sekretariat DPRD Kota Singkawang sebagai tindak lanjut dari peraturan Pemerintah RI Nomor 41 Tahun 2007 tentang Organisasi Perangkat Daerah, seperti yang tertera dalam Rencana Strategis
(RENSTRA) Tahun 2013-2017, Sekretariat Dewan Perwakilan Rakyat Daerah (DPRD) Kota Singkawang merupakan unsur pelayanan terhadap DPRD yang secara teknis operasional berkedudukan di bawah dan bertanggung jawab kepada Walikota melalui Sekretaris Daerah. Sekretariat Dewan Perwakilan Rakyat Daerah (DPRD) Kota Singkawang merupakan sebuah lembaga atau instansi, di mana di dalamnya terdapat birokrasi atau sistem kontrol yang kompleks dan terstruktur dalam pembagian tugas masing-masing bagian.

Terdapat empat bagian utama dalam instansi tersebut, yaitu Bagian Administrasi Umum, Bagian Anggaran, Bagian Hukum, Persidangan dan Risalah serta Bagian Hubungan Antar Lembaga, Humas, Protokol dan Perpustakan, di manadalam setiap bagian tersebut terdiri atas beberapa subbagian. Bagian Administrasi Umum terdiri atas Sub Bagian Tata Usaha, Sub Bagian Umum dan Kekayaan, serta Sub Bagian Perencanaan dan Laporan. Bagian Anggaran terdiri dari Sub Bagian Anggaran serta Sub Bagian Pembendaharaan dan Pembukuan. Bagian Hukum, Persidangan dan Risalah terdiri dari Sub Bagian Kajian Hukum dan Perundangundangan, Sub Bagian Risalah dan Notulen, serta Sub Bagian Persidangan dan Rapat. Bagian Hubungan Antar Lembaga, Humas, Protokol dan Perpustakaan terdiri dari Sub Bagian Hubungan Antar Lembaga, Sub Bagian Humas dan Protokol, serta Sub Bagian Perpustakaan.

Tugas pokok, Fungsi dan Tata Kerja Sekretariat DPRD Kota Singkawang ditetapkan berdasarkan peraturan Walikota SingkawangNomor2Tahun2009, sepertiyang tertera dalam Rencana Strategis (RENSTRA) Tahun 2013-2017. Bagian Administrasi Umum secara keseluruhan mempunyai tugas mengkoordinasikan penyusunan program dan penyelenggaraan tugas-tugas administrasi umum meliputi urusan ketatausahaan, administrasi kepegawaian, administrasi keanggotaan DPRD, perjalanan dinas, rumah tangga, umum dan kekayaan, perencanaan dan pelaporan. Secara keseluruhan, Bagian Hukum, Persidangan dan Risalah 
mempunyai tugas melakukan pengkajian produk hukum DPRD dan peraturan perundang-undangan, penyusunan risalah dan notulen serta pelaksanaan persidangan dan rapat. Bagian Hubungan Antar Lembaga, Humas, Protokol dan Perpustakaan secara keseluruhan mempunyai tugas memfasilitasi hubungan antar lembaga, humas, protokol dan perpustakaan. Bagian Anggaran secara keseluruhan mempunyai tugas mengkoordinasikan penyusunan program dan penyelenggaraan tugas bagian anggaran meliputi penyusunan rencana anggaran dan pengelolaan perbendaharaan dan pembukuan.

Terlihat jelas betapa kompleks dan terstrukturnya aktifitas kerja dalam instansi tersebut. Sehingga memungkinkan terjadinya kendala-kendala yang dialami oleh para pegawai dalam menjalankan tugas dan fungsinya yang kemudian berdampak pada kinerja serta kepuasan mereka terhadap komunikasi organisasi yang terjalan dalam instansi tersebut. Terkait hal ini, komunikasi yang harmonis antar seluruh pegawai mutlak diperlukan guna mencapai hasil kerja yang memuaskan serta dapat mensukseskan setiap acara atau kegiatan yang diadakan melalui koordinasi yang terjalin baik dengan seluruh bagian.

Berdasarkan dari hasil preeliminary research yang peneliti lakukan, peneliti menemukan beberapa permasalahan seputar komunikasi organisasi yang terjadi dalam instansi tersebut, seperti pada saat menerima Kunjungan Kerja (kunker) dari Dewan Perwakilan Rakyat Daerah Kabupaten Pati pada tanggal 3 Agustus 2015. Pegawai yang bertugas mengurus sound system di ruang utama sedang tidak berada di tempat, sehingga pertemuan harus dimulai tanpa menggunakan microphone. Namun, masalah tersebut segera diatasi oleh pegawai yang sedang berada di sana saat itu. Sehingga pertemuan dapat berjalan dengan sebagaimana mestinya. Terkait kejadian tersebut, dapat terlihat kurangnya koordinasi oleh pegawai antar bagian dalam Instansi tersebut.

Selain itu, peneliti juga menemukan masalah yang terjadi seputar penyebarluasan informasi yang berkaitan dengan pekerjaan dan instansi. Saat itu, instansi mendapat surat edaran dari Walikota Singkawang untuk melakukan kegiatan kerja bakti dalam rangka menyambut Hari Kemerdekaan Republik Indonesia ke-7o tahun, pada hari Jum'at 14 Agustus 2015. Sehubungan dengan akan diadakannya kerja bakti tersebut, maka instansi memutihkan absensi para pegawai di hari tersebut. Namun, beberapa pegawai ternyata tidak mengetahui informasi seputar kegiatan kerja bakti serta pemutihan absensi di hari itu. Sehingga, pada hari itubeberapa pegawai yang tidak mengetahui informasi tersebut tetap berangkat ke kantor dan beraktifitas seperti biasa serta melakukan absensi sidik jari.

Sebelumnya juga pernah terjadi sedikit kendala pada saat acara Pelantikan Anggota Dewan Perwakilan Rakyat Daerah(DPRD) Kota Singkawang periode 2014-2019 $(\mathrm{CH}$, n.d.). Acara pelantikan tersebut juga dihadiri oleh Gubernur Kalimantan Barat Cornelis, Walikota Singkawang Awang Ishak, Ketua TP PKK Provinsi Kalimantan Barat Frederika Cornelis, Wakil Walikota Singkawang, Instansi Vertikal, serta SKPD Provinsi dan Kota Singkawang. Pada acara pelantikan tersebut, Cornelis selaku Gubernur Kalimantan Barat terkejut saat mengetahui bahwa anggota DPRD Kota Singkawang periode 2014-2019 yang baru diambil sumpahnya sebagai wakil rakyat di aula DPRD Kota Singkawang pada tanggal 16 September 2014, ternyata belum semua mendapatkan emblem. Padahal emblem tersebut seharusnya sudah disiapkan jauh-jauh hari sebelum hari pelantikan. Terkait hal ini, dapat dilihat bahwa kurangnya persiapan yang dilakukan oleh pegawai yang bertanggung jawab mengurus kelengkapan emblem tersebut. Kejadian seperti ini tidak seharusnya terjadi, mengingat acara tersebut juga dihadiri oleh orang nomor satu di Kalimantan Barat.

Terkait permasalahan di atas, dapat dikatakan bahwa komunikasi yang efektif memegang peranan yang sangat penting dalam sebuah lembaga atau instansi. Masalah seputar kepuasan komunikasi organisasi 
serta pengaruhnya terhadap kinerja pegawai di Sekretariat DPRD Kota Singkawang, merupakan hal yang sangat menarik untuk diteliti. Sebab, Sekretariat DPRD Kota Singkawang memiliki visi "Terwujudnya Pelayanan yang Profesional Untuk Mengantarkan DPRD Kota Singkawang Menjadi Lembaga yang Terpercaya”. Untuk dapat mewujudkan pelayanan yang profesional, diperlukan kerja sama yang baik dari semua pihak yang terlibat dalam instansi tersebut. Selain itu, kinerja para pewagai yang maksimal menjadi syarat utama bagi instansi untuk dapat memberikan pelayanan yang memuaskan.Jika instansi saja tidak dapat memberikan pelayanan yang memuaskan bagi para pegawainya, bagaimana mungkin para pegawai serta instansi tersebut dapat memberikan pelayanan yang maksimal seperti yang diharapkan.

Keberadaan Sekretariat DPRD Kota Singkawang juga sangat menentukan keberhasilan kinerja anggota dan lembaga DPRD Kota Singkawang. Sesuai dengan tugas pokok dan fungsinya, Sekretariat DPRD bertindak sebagai unsur pendukung bagi DPRD dalam menjalankan fungsi, tugas dan wewenangnya. Selain itu, Sekretariat DPRD Kota Singkawang juga memiliki posisi yang sangat strategis dalam mewujudkan visi dan misi Pemerintah Kota Singkawang,sebagaimana tertuang dalam Rencana Pembangunan Jangka Menengah Daerah (RPJMD) Kota Singkawang tahun 2013-2017, seiring diberlakukannya Peraturan Pemerintah RI Nomor 41 Tahun 2007, serta untuk memenuhi paradigma desentralisasi yang berkesinambungan, maka struktur Sekretariat DPRD Kota Singkawang mempunyai tugas pokok dan fungsi yang dapat mendukung langsung fungsi-fungsi dari DPRD Kota Singkawang.

Berdasarkan permasalahan di atas, maka masalah dalam penelitian ini dapat dirumuskan sebagai berikut, "Adakah pengaruh kepuasan komunikasi organisasi terhadap kinerja pegawai di Sekretariat DPRD Kota Singkawang ?".Penelitian ini bertujuan untuk menemukan pengaruh kepuasan komunikasi organisasi terhadap kinerja pegawai di Sekretariat DPRD Kota Singkawang. Hasil dari penelitian ini diharapkan mampu memberikan masukan dan manfaat kepada pihak Sekretariat DPRD Kota Singkawang. Agar memperhatikan kepuasan komunikasi organisasi para pegawai, sehingga dapat berpengaruh positif terhadap kinerja pegawai. Selain itu, hasil dari penelitian ini juga diharapkan mampu memberikan manfaat serta sebagai acuan bagi penelitian selanjutnya, serta dapat memperkaya wawasan ilmu komunikasi, terutama seputar komunikasi organisasi terkait pengaruh antara kepuasan komunikasi organisasi terhadap kinerja pegawai.

\section{TINJAUAN PUSTAKA}

\section{Kepuasan Wujud Keberhasilan Organisasi}

Kepuasan terhadap komunikasi organisasi merupakan faktor penting yang harus diperhatikan oleh setiap organisasi atau instansi. Karena, setiap pegawai yang menjalankan aktivitas-aktivitas di dalam sebuah organisasi merupakan seorang individu yang memiliki kebutuhan bermacam-macam, serta selalu berusaha untuk memuaskan kebutuhannya tersebut. Kepuasan komunikasi organisasi adalah semua tingkat kepuasan seorang karyawan mempersepsi lingkungan komunikasi secara keseluruhan. Kepuasan dalam pengertian ini menunjukkan kepada bagaimana baiknya informasi yang tersedia memenuhi persyarataan permintaan anggota organisasi akan tuntutan bagi informasi, dari siapa datangnya, cara disebarluaskan, bagaimana diterima, diproses dan apa respon orang yang menerima. Kepuasan komunikasi adalah satu fungsi dari apa yang seorang dapatkan dengan apa yang dia harapkan (Masmuh, 2008). Kepuasan terhadap kebutuhan akan membantu para pegawai dalam menjalankan setiap aktivitasnya dengan baik.

Syarat kepuasan komunikasi mengacu pada kepuasan dari seseorang terhadap hubungan dan aliran informasi(Alsayed, Motaghi, \& Osman, 2012). Kepuasan menggambarkan suatu konsep individu dan konsep mikro. Kepuasan juga merupakan 
gambaran dari evaluasi atas suatu keadaan internal yang menggambarkan reaksi afektif seseorang terhadap hal-hal yang diinginkan, berkaitan dengan komunikasi yang terjalin dalam sebuah organisasi. Secara keseluruhan, kepuasan berhubungan dengan perbedaan antara apa yang orang inginkan dari sudut pandang komunikasi dalam organisasi dengan apa yang orang tersebut miliki dalam kaitan tersebut. Kepuasan juga berhubungan dengan kenyamanan, jadi kepuasan dalam komunikasi berarti seseorang merasa nyaman dengan pesan-pesan, media dan hubunganhubungan dalam organisasi (Wayne Pace \& Faules, 2013).

Kepuasan dengan komunikasi muncul dari kombinasi beberapa faktor, yaitu kepuasan dengan pekerjaan, kepuasan dengan ketepatan informasi, kepuasan dengan kemampuan seseorang yang menyarankan penyempurnaan, kepuasan dengan efisiensi bermacam-macam saluran komunikasi, kepuasan dengan kualitas media, kepuasan dengan cara komunikasi teman sekerja, serta kepuasan dengan keterlibatan dalam komunikasi organisasi sebagai suatu kesatuan. Kepuasan dengan pekerjaan mencakup hal-hal yang berkenaan dengan pembayaran, keuntungan, naik pangkat, pekerjaan itu sendiri. Kepuasan dengan ketepatan informasi mencakup tentang tingkat kepuasan dengan informasi, kebijaksanaan, teknik-teknik baru, perubahan administratif dan staf, rencana masa datang dan penampilan pribadi.

Kepuasandengan kemampuanseseorang yang menyarankan penyempurnaan mencakup hal-hal sebagai tempat di mana komunikasi seharusnya disempurnakan, pemberitahuan mengenai perubahan untuk tujuan penyempurnaan dan strategi khusus yang digunakan dalam membuat perubahan. Kepuasandenganefisiensibermacam-macam saluran komunikasi mencakup melalui mana komunikasi disebarluaskan dalam organisasi, mencakup peralatan, buletin, memo, materi tulisan. Kepuasan dengan kualitas media mencakup berapa baiknya mutu tulisan, nilai informasi yang diterima, keseimbangan informasi yang tersedia dan ketepatan informasi yang datang. Kepuasan dengan cara komunikasi teman sekerja mencakup komunikasi horizontal, informal dan tingkat kepuasan yang timbul dari diskusi masalah dan mendapatkan informasi dan teman sekerja. Kepuasan dengan keterlibatan dalam komunikasi organisasi sebagai suatu kesatuan mencakup hal-hal keterlibatan hubungan dengan organisasi, dukungan atau bantuan dari organisasi dan informasi dari organisasi (Masmuh, 2008).

Organisasi atau instansi mutlak membutuhkan komunikasi bagi kelangsungan hidup organisasi tersebut. Komunikasi organisasi menjadi faktor penting terhadap jalannya keseluruhan fungsi suatu organisasi atau instansi (Rajhans, 2012). Komunikasi organisasi juga dipandang sebagai faktor penyebab efektif dan tidak efektifnya kerja fungsional suatu organisasi atau sebagai suatu gejala bahwa organisasi tersebut berfungsi secara efektif atau tidak atau sebagai gejala tidak sehatnya suatu organisasi (Kriyantono, 2006).

Komunikasi organisasi dapat didefinisikan sebagai pertunjukan dan penafsiran pesan di antara unit-unit komunikasi yang merupakan bagian dari suatu organisasi tertentu. Komunikasi organisasi terjadi kapanpun setidak-tidaknya satu orang yang menduduki suatu jabatan dalam suatu organisasi menafsirkan suatu pertunjukan. Suatu organisasi terdiri dari unit-unit komunikasi dalam hubungan-hubungan hierarkis antara yang satu dengan lainnya dan berfungsi dalam suatu lingkungan (Wayne Pace \& Faules, 2013).

Tujuan dari komunikasi organisasi adalah untuk membantu memudahkan, melaksanakan serta melancarkan jalannya fungsi suatu organisasi (Ruliana, 2014). Hubungan komunikasi yang terjalin harmonis antar semua pihak internalnya menjadi tolak ukur atas kesuksesan atau keberhasilan dari sebuah organisasi. Komunikasi memungkinkan terjadinya koordinasi kegiatan yang dilakukan oleh semua pihak yang terlibat dalam sebuah organisasi atau instansi. Tanpa adanya komunikasi tidak mungkin akan terjalin koordinasi yang baik antar semua 
pegawai dari masing-masing bagian dalam sebuah organisasi.Selain itu, komunikasi juga penting bagi keberfungsian suatu organisasi atau instansi dalam mencapai tujuannya. Melalui komunikasi para anggota anggota organisasi dapat mendefinisikan tujuan, menggambarkan peran dan tanggung jawab anggota, mengoordinasikan pelaksanaan pekerjaan, serta membentuk jaringan informasi. Komunikasi yang efektif membantu organisasi untuk memperkuat karyawan guna mencapai tujuan organisasi (Abdullah \& Hui, 2014). Komunikasi menjadi dasar bagi para pegawai untuk dapat memahami organisasi atau instansi (Rajhans, 2012). Melalui komunikasi para anggota organisasi dapat mendefinisikan tujuan, menggambarkan peran dan tanggung jawab anggota, mengoordinasikan pelaksanaan pekerjaan, serta membentuk jaringan informasi.

Hubungan antara atasan dan para pegawainya juga berpengaruh besar dalam terwujudnya keberhasilan organisasi. Seorang pegawai akan merasa lebih puas dengan pekerjaan mereka apabila terdapat keterbukaan komunikasi antara atasan dengan para pegawainya. Kesediaan atasan untuk berbincang-bincang mengenai sebuah topik bersama dengan pegawainya akan meningkatkan hubungan baik dalam sebuah organisasi atau instansi. Sikap atasan yang negatif terhadap para pegawainya akan menghambat interaksi yang terjadi di antara keduanya. Hal ini akan mempengaruhi kepuasan kerja dari seorang pegawai yang pada dasarnya berkorelasi positif terhadap pola komunikasi bersama atasan. Kepuasan kerja bawahan juga berkaitan erat dengan kredibilitas seorang atasan.Komunikasi yang terjalin antara atasan dan para pegawainya dipengaruhi oleh beberapa faktor, yaitu keterbukaan, kepercayaan pada pesan tulisan, pesan yang berlebihan, timing (ketepatan waktu) dan penyaringan.

\section{Kinerja Sebagai Indikator Kepuasan Komunikasi Organisasi}

Kinerja adalah hasil kerja secara kualitas dan kuantitas yang dicapai oleh seorang karyawan dalam melaksanakan tugasnya sesuai dengan tanggung jawab yang diberikan kepadanya (Ruliana, 2014). Kinerja seseorang merupakan gabungan dari kemampuan, usaha dan kesempatan yang dapat diukur dari akibat yang dihasilkannya. Kinerja bukan menyangkut karakteristik pribadi yang ditunjukkan oleh seseorang melalui hasil kerja yang telah dan akan dilakukan seseorang. Kinerja dapat pula diartikan sebagai kesuksesan individu dalam melakukan pekerjaannya. Ukuran kesuksesan kinerja tersebut didasarkan pada ukuran yang berlaku dan disesuaikan dengan jenis pekerjaannya(Umam, 2010).

Kinerja juga merupakan gambaran mengenai tingkat pencapaian pelaksanaan suatu kegiatan/program/kebijaksanaan dalam mewujudkan sasaran, tujuan, misi dan visi organisasi yang tertuang dalam perumusan skema strategis (strategic planning) suatu organisasi (Fahmi, 2013). Agar dicapai kinerja yang profesional, hal-hal seperti kesukarelaan, pengembangan diri pribadi, pengembangan kerja sama yang saling menguntungkan, serta partisipasi seutuhnya perlu dikembangkan (Umam, 2010).

Terdapat enam kriteria primeryang dapat digunakan untuk mengukur kinerja, yaitu quality, quantity, timeliness, cost effectiviness, need for supervisor, dan interpersonal impact. Quality mencakuptingkat sejauh mana proses atau hasil pelaksanaan kegiatan mendekati kesempurnaan atau mendekati tujuan yang diharapkan. Quantity mencakup jumlah yang dihasilkan, misalkan jumlah rupiah, jumlah unit, jumlah siklus, kegiatan yang diselesaikan. Timeliness mencakup tingkat sejauh mana suatu kegiatan diselesaikan pada waktu yang dikehendaki dengan memerhatikan koordinasi output lain serta waktu yang tersedia untuk kegiatan lain. Cost effectiviness mencakup tingkat sejauh mana penggunaan daya organisasi (manusia, keuangan, teknologi, material) dimaksimalkan untuk mencapai hasil tertinggi atau pengurangan kerugian dari setiap unit penggunan sumber daya. Need for supervisor mencakup tingkat sejauh 
mana seorang pegawai dapat melaksanakan suatu fungsi pekerjaan tanpa memerlukan pengawasan seorang supervisor untuk mencegah tindakan yang kurang diinginkan. Interpersonal impact mencakup tingkat sejauh mana pegawai memelihara harga diri, nama baik dan kerja sama di antara rekan kerja dan bawahan.(Ruliana, 2014).

Sebuah organisasi atau instansi mutlak membutuhkan partisipasi para pegawainya dalam mewujudkan visi dan misi organisasi. Banyak hal yang harus diperhatikan oleh setiap organisasi atau instansi dalam peningkatan kinerja para pegawai selaku aset terpenting bagi sebuah organisasi atau instansi. Terwujudnya kinerja yang maksimal tidak lepas dari kualitas baik yang dimiliki oleh sumber daya manusianya. Downs dan Adrian menyatakan bahwa karyawan yang mendapatkan informasi dengan baik oleh organisasi akan lebih memahami kebutuhan pekerjaan mereka dan harapan kontribusi mereka terhadap keberhasilan organisasi (Abdullah \& Hui, 2014).

Kinerja yang maksimal dari para pegawai menjadi syarat utama bagi instansi untuk dapat memberikan pelayanan yang memuaskan.Jika instansi saja tidak dapat memberikan pelayanan yang memuaskan bagi para pegawainya, bagaimana mungkin para pegawai serta instansi tersebut dapat memberikan pelayanan yang memuaskan seperti yang diharapkan. Maka dari itu, diperlukan kerja sama yang baik antara organisasi dengan para pegawai, guna terwujudnya tujuan bersama.

Proses komunikasi serta kepuasan komunikasi organisasi memegang peranan penting dalam sebuah instansi. Bila instansi dapat memenuhi segala kebutuhan serta harapan dari para pegawai, maka kepuasan komunikasi organisasi mereka dapat terpenuhi, sehingga membuat para pegawai dapat bekerja dengan maksimal. Kepuasan terhadap komunikasi organisasi merupakan faktor penting yang harus diperhatikan oleh organisasi atau instansi, agar para pegawai dapat bekerja dengan baik dan maksimal, sehingga visi dan misi organisasi dapat terwujud.
Setiap pegawai yang menjalankan aktivitas-aktivitas dalam organisasi merupakan individu yang memiliki kebutuhan bermacam-macam, serta selalu berusaha untuk memuaskan kebutuhannya tersebut. Kebutuhan pribadi yang dimiliki oleh setiap pegawai secara tidak langsung dapat berpengaruh terhadap organisasi. Kepuasan akan kebutuhan tersebut akan berpengaruh terhadap sikap dan perilaku para pegawai. Hal ini secara tidak langsung akan berdampak pada kinerja para pegawai dalam menyelesaikan pekerjaannya. Kepuasan akan kebutuhan dapat membantu para pegawai dalam menjalankan setiap aktivitasnya dengan baik. Jika para pegawai merasa puas terhadap komunikasi yang terjalin dalam sebuah organisasi, maka diharapkan hal tersebut akan berpengaruh positif terhadap kinerja para pegawai. Kepuasan terhadap komunikasi organisasi dipengaruhi oleh aspek-aspek organisasi seperti dipercaya, sokongan dan tujuan kinerja yang tinggi (Masmuh, 2008).

Keseluruhan kinerja organisasi dapat ditingkatkan ketika karyawan mendapatkan informasi secara memadai melalui komunikasi yang efektif. Kepuasan komunikasi bukan hanya faktoryang menilai kinerja pada level formal, tetapi juga meningkatkan kemampuan karyawan untuk bekerja semaksimal mungkin. Dengan kata lain, kinerja menjadi salah satu indikator kepuasan komunikasi organisasi. Dua aspek utama dari pengaruh komunikasi pada indikator kinerja adalah hubungan dan kepuasan komunikasi organisasi.

Maka dari itu, diperlukan upaya-upaya untuk membangun komunikasi efektif yang berawal dari hubungan interpersonal yang baik antar anggota organisasi atau instansi. Saat pegawai merasa puas dengan komunikasi organisasi yang terjalin, mereka akan memiliki hubungan yang sehat, dan arus informasi yang mengalir bebas. Karena faktor-faktor ini, pekerjaan mereka akan menjadi sangat mudah untuk dicapai/diselesaikan dan kemampuan mereka dalam melakukan pekerjaan menjadi lebih baik. Hasil studi menunjukkan bahwa terdapat 
hubungan yang signifikan antara kepuasan komunikasi karyawan terhadap kinerja mereka. Terdapat tiga komponen kepuasan komunikasi yang memiliki dampak signifikan terhadap indikator kinerja karyawan. Hubungan positif yang signifikan yang sejalan denganhasil studi laindapat dikaitkan dengan kebutuhan karyawanpada kedua aspek komunikasi, seperti informasi dan hubungan komunikasi (Alsayed et al., 2012).

\section{Kerangka Berfikir}

Dari uraian teori di atas, penulis membuat kerangka berfikir sebagai berikut:

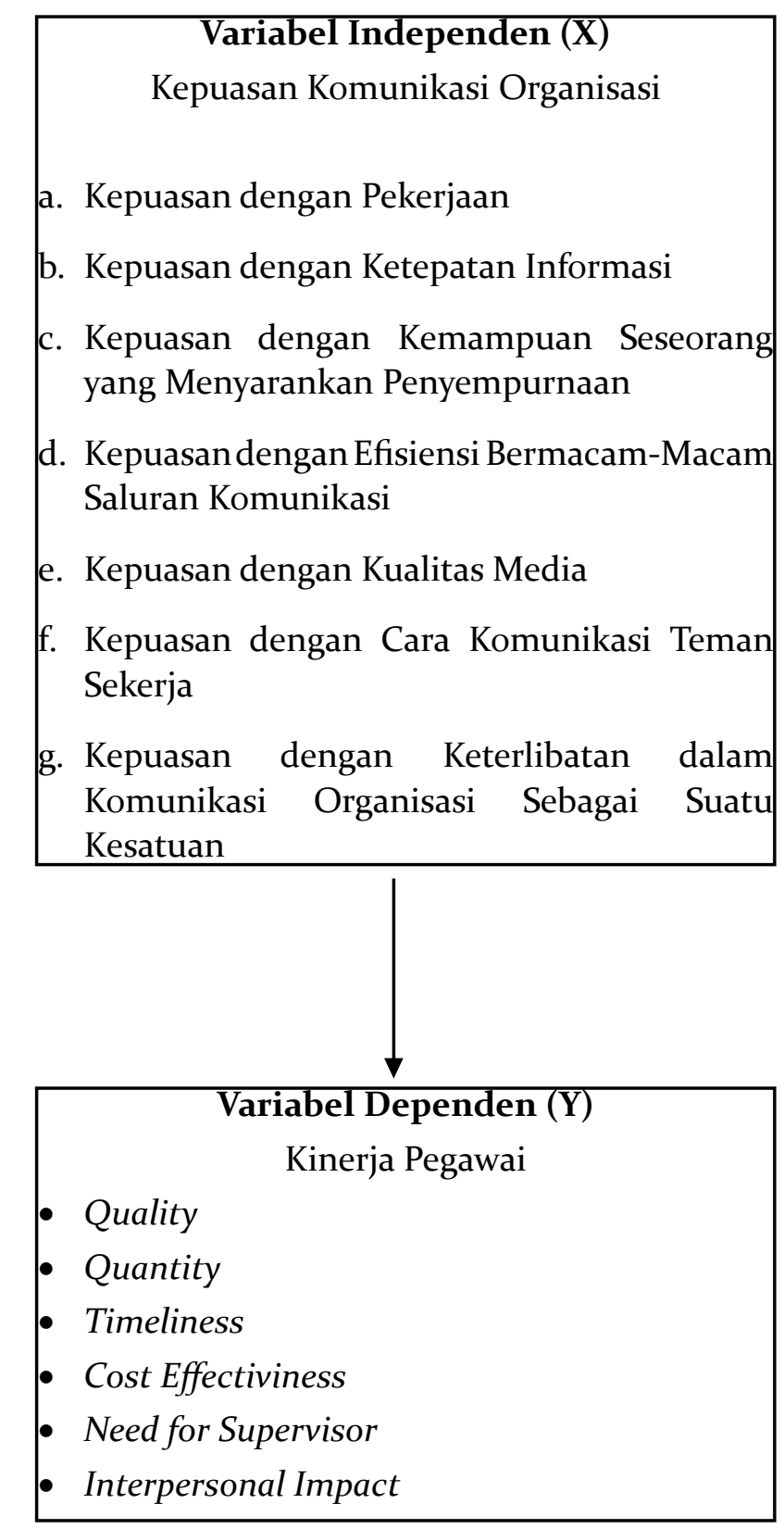

Bagan.1 Kerangka Pemikiran

\section{Hipotesis}

Dalam penelitian ini, peneliti merumuskan hipotesis sebagai berikut:

Ho: Tidak ada pengaruh Kepuasan Komunikasi Organisasi Terhadap Kinerja Pegawai Sekretariat DPRD Kota Singkawang.

Ha: Ada pengaruh Kepuasan Komunikasi Organisasi Terhadap Kinerja Pegawai Sekretariat DPRD Kota Singkawang.

\section{METODE}

Penelitian ini menggunakan jenis penelitian kuantitatif, yaitu penelitian yang menggambarkan atau menjelaskan suatu masalah yang hasilnya dapat digeneralisasikan. Dengan demikian tidak terlalu mementingkan kedalaman data atau analisis (Kriyantono, 2006). Metode yang digunakan dalam penelitian ini adalah metode survey, di mana peneliti memilih sejumlah responden sebagai sampel dan menggunakan kuesioner sebagai instrumen pengumpulan datanya (Morissan, 2012). Terdapat dua variabel dalam penelitian ini, yaitu kepuasan komunikasi organisasi sebagai variabel independen (X) dan kinerja pegawai sebagai variabel dependen $(\mathrm{Y})$.

Penelitian ini berlokasi di Kantor Sekretariat DPRD Kota Singkawang Provinsi Kalimantan Barat. Beralamat di Jalan Firdaus H.Rais No. 2, Kode Pos: 79123, No. Telp.(0562) 632455 - 633403, No. Fax. (0562) 634062. Penelitian ini dilakukan selama kurang lebih 1 (satu) bulan, terhitung dari pertengahan Mei - pertengahan Juni 2016.

Penelitian ini terdiri dari dua sumber data, yaitu sumber data primer dan sumber data sekunder. Data primer adalah data yang dikumpulkan sendiri oleh peneliti langsung dari sumber pertama atau tempat objek penelitian dilakukan (Siregar, 2013). Dalam penelitian ini, data primer didapat dari hasil kuesioner. Data sekunder adalah data yang diperoleh dari sumber kedua atau sumber sekunder. Karena data sekunder ini bersifat melengkapi data primer, kita dituntut hatihati atau menyeleksi data sekunder jangan 
sampai data tersebut tidak sesuai dengan tujuan riset kita atau mungkin terlalu banyak (Kriyantono, 2006: 42). Dalam penelitian ini data sekunder didapat dari berita, dokumen, dokumentasi serta data-data lain yang berkaitan dengan penelitian ini.

Dalam penelitian ini peneliti menggunakan Kuesioner (angket) sebagai teknik pengumpulan data. Serangkaian daftar pernyataan dibuat dan disusun secara sistematis berdasarkan sejumlah indikator yang digunakan sebagai alat untuk mengukur masingmasing variabel. Penyebaran kuesioner ditujukan untuk mencari dan mengumpulkan informasi yang lengkap seputar kepuasan komunikasi organisasi selaku variabel independen $(\mathrm{X})$ dan kinerja pegawai selaku variabel dependen (Y). Kuesioner atau angket yang digunakan bersifat tertutup, yaitu suatu angket di mana responden diminta memilih suatu jawaban dari suatu daftar jawaban yang disediakan peneliti(Morissan, 2012).

Skala pengukuranyang digunakan dalam penelitian ini adalah skala likert. Skala likert digunakan untuk mengukur sikap seseorang tentang sesuatu objek sikap. Indikatorindikator dari variabel sikap terhadap suatu objek merupakan titik tolak dalam membuat pertanyaan atau pernyataan yang harus diisi responden. Setiap pertanyaan atau pernyataan tersebut dihubungkan dengan jawaban yang berupa dukungan atau pernyataan sikap yang diungkapkan dengan kata-kata: Sangat Setuju (SS); Setuju (S); Netral (N); Tidak Setuju (TS); Sangat Tidak Setuju (STS) atau Sangat Puas; Puas; Cukup Puas; Tidak Puas; Sangat Tidak Puas atau Sangat Baik; Baik; Sedang; Buruk; Sangat Buruk, dan lainnya tergantung indikator penelitian (Kriyantono, 2006). Instrumen penelitian yang menggunakan skala likert dapat dibuat dalam bentuk checklist ataupun pilihan ganda (Sugiyono, 2015).

Populasi dalam penelitian ini adalah seluruh Pegawai Negeri Sipil (PNS) di Sekretariat Dewan Perwakilan Rakyat Daerah (DPRD) Kota Singkawang yang berjumlah sebanyak 35 orang. Teknik sampel yang digunakan dalam penelitian ini adalah sampel Jenuh. Sampel Jenuh adalah teknik penentuan sampel bila semua anggota populasi digunakan sebagai sampel. Hal ini sering dilakukan bila jumlah populasi relatif kecil, kurang dari 30 orang, atau penelitian yang ingin membuat generalisasi dengan kesalahan yang sangat kecil(Sugiyono, 2015). Dengan kata lain, sampel dalam penelitian ini merupakan seluruh populasi yang berjumlah 35 Orang.

Teknik validitas data dalam penelitian ini menggunakan uji validitas konstruk. Menguji validitas konstruk dilakukan dengan cara menguji kuesioner yang telah dibuat, apakah valid atau tidak (Siregar, 2013). Ada beberapa kriteria yang dapat digunakan untuk mengetahui kuesioneryang digunakan sudah tepat untuk mengukur apa yang ingin diukur, yaitu:

1. Jika koefisien korelasi product moment melebihi 0,3

2. Jika koefisien korelasi product moment > r-tabel $(\alpha ; n-2) n=j u m l a h$ sampel

3. Rumus yang digunakan untuk uji validitas konstruk dengan teknik korelasi product moment, yaitu:

$\mathrm{r}_{\text {hitung }}=\frac{\left(\mathrm{N}\left(\sum \mathrm{XY}\right)-\left(\sum \mathrm{X} \sum \mathrm{Y}\right)\right)}{\sqrt{ }\left(\left[\mathrm{N} \sum \mathrm{X}^{2}-\left(\sum \mathrm{X}\right)^{2}\right]\left[\mathrm{N} \sum \mathrm{Y}^{2}-\left(\sum \mathrm{Y}\right)^{2}\right]\right)}$

Di mana:

$\mathrm{N}=$ Jumlah responden

$\mathrm{X}=$ Skor variabel (jawaban responden)

$\mathrm{Y}=$ Skor total dari variabel (jawaban responden)

Penelitian ini menggunakan uji reliabilitas dengan teknik Alpha Cronbach. Kriteria suatu instrumen penelitian dikatakan reliabel dengan menggunakan teknik ini bila koefisien reliabilitas $\left(r_{11}\right)>0,6$ (Siregar, 2013). Kriteria besarnya koefisien reliabilitas adalah(Arikunto, 2006):
$0,80<\mathrm{r} 11 \leq 1$, oo reliabilitas sangat tinggi
$\mathrm{o}, 6 \mathrm{o}<\mathrm{r} 11 \leq \mathrm{o}, 8 \mathrm{o}$ reliabilitas tinggi
$0,40<\mathrm{r} 11 \leq 0,60$ reliabilitas cukup
$0,20<\mathrm{r} 11 \leq 0,40$ reliabilitas rendah
$\mathrm{o}, \mathrm{oo}<\mathrm{r} 11 \leq \mathrm{0}, 2 \mathrm{O}$ reliabilitas sangat rendah 
Tahapperhitungan uji reliabilitas dengan menggunakan teknik alpha cronbach, yaitu:

a. Menentukan nilai varians setiap butir pertanyaan

$$
\sigma_{i}^{2}=\frac{\sum X_{i}^{2}-\frac{\left(\sum X_{i}\right)^{2}}{n}}{n}
$$

b. Menentukan nilai varians total

$$
\sigma_{i}^{2}=\frac{\sum X^{2}-\frac{\left(\sum X\right)^{2}}{n}}{n}
$$

c. Menentukan reliabilitas instrumen

$$
\mathrm{r}_{\mathrm{n}}=\left[\frac{k}{k-1}\right]\left[1-\frac{\sum \sigma_{b}^{2}}{\sigma_{t}^{2}}\right]
$$

Di mana :

$\mathrm{n}$ = Jumlah sampel

$\mathrm{X}_{\mathrm{i}}=$ Jawaban responden untuk setiap butir pertanyaan

$\sum \mathrm{X}=$ Total jawaban responden untuk setiap butir pertanyaan

$\sigma_{t}^{2}=$ Varians total

$\sum \sigma_{b}^{2}=$ Jumlah varians butir

$\mathrm{k}=$ Jumlah butir pertanyaan

$r_{11}=$ Koefisien reliabilitas instrument

Teknik analisis data yang digunakan dalam penelitian ini adalah teknik analisis regresi linear sederhana, yaitu jika terdapat data dari dua variabel riset yang sudah diketahui yang mana variabel bebas $\mathrm{X}$ dan yang mana variabel terikat $Y$ sedangkan nilai-nilai Y lainnya dapat dihitung atau diprediksi berdasarkan suatu nilai X tertentu (Kriyantono, 2006). Rumus Regresi Linear Sederhana sebagai berikut:

$$
\mathrm{Y}=\mathrm{a}+\mathrm{bX}
$$

Di mana:

Y = Variabel tidak bebas (subjek dalam variabel tak bebas/dependen yang diprediksi)

$\mathrm{X}=$ Variabel bebas (subjek pada variabel independen yang mempunyai nilai tertentu) $\mathrm{a}=$ Nilai intercept (konstan) atau harga Y bila $\mathrm{X}=\mathrm{o}$

$\mathrm{b}=$ Koefisien regresi, yaitu angka peningkatan atau penurunan variabel dependen yang didasarkan pada variabel independen. Bila $b(+)$ maka naik, bila b (-) maka terjadi penurunan.

Nilai a dihitung dengan rumus:

$$
\mathrm{a}=\frac{\sum \mathrm{Y}\left(\sum \mathrm{X}^{2}\right)-\sum \mathrm{X} \sum \mathrm{XY}}{\mathrm{n} \sum \mathrm{X}^{2}-\left(\sum \mathrm{X}\right)^{2}}
$$

Nilai b dihitung dengan rumus:

$$
\frac{\mathrm{b}=\mathrm{n} \sum \mathrm{XY}-\sum \mathrm{X} \sum \mathrm{XY}}{\mathrm{n} \sum \mathrm{X}^{2}-\left(\sum \mathrm{X}\right)^{2}}
$$

\section{Uji t}

Dalam penelitian ini, uji t digunakan untuk melakukan pengujian signifikansi koefisien regresi, yaitu signifikansi dari pengaruh kepuasan komunikasi organisasi terhadap kinerja pegawai. Langkah-langkah untuk melakukan uji t sebagai berikut:

a. Menentukan $\mathrm{H}_{\mathrm{o}}$ dan $\mathrm{H}_{1}$ $\mathrm{H}_{\mathrm{o}}: \mathrm{b}_{1}=\mathrm{o}$;Tidakterdapatbesaranpengaruh kepuasan komunikasi organisasi (X) terhadap kinerja pegawai (Y).

Ha: $b_{1} \neq 0$; Terdapat besaran pengaruh kepuasan komunikasi organisasi (X) terhadap kinerja pegawai (Y).

b. Menentukan Level of Significant $\alpha=5 \%$

c. Menghitung nilai $\mathrm{t}$

$\mathrm{T}_{\text {hitung }}=\frac{\mathrm{b}}{\mathrm{S}_{\mathrm{b}}}$

Dimana:

$\mathrm{b}=$ Koefisien regresi

$\mathrm{S}_{\mathrm{b}}=$ Standar eror koefisien regresi(Siregar, 2013)

d. Kriteria pengujian

$\mathrm{H}_{\mathrm{o}}$ diterima jika $-\mathrm{t}_{\text {tabel }} \leq \mathrm{t}_{\text {hitung }} \leq \mathrm{t}_{\text {tabel }}$ $\mathrm{H}_{\mathrm{o}}$ ditolak jika $\mathrm{t}_{\text {hitung }}<-\mathrm{t}_{\text {tabel }}$ atau $\mathrm{t}_{\text {hitung }}>$ $t_{\text {tabel }}$

e. Kesimpulan

Untuk mengetahui apakah $\mathrm{H}_{\mathrm{o}}$ di tolak 
atau diterima dilakukan dengan cara membandingkan hasil perhitungan signifikansi dengan level of significant $=$ $5 \%(0,05)$. Apabila $t_{\text {hitung }}>\mathrm{t}_{\text {tabel }}$ maka $\mathrm{H}_{\mathrm{o}}$ ditolak, hal ini menunjukkan adanya besaran pengaruh yang signifikan antara variabel $X$ terhadap variabel Y. Sedangkan jika $\mathrm{t}_{\text {hitung }}<\mathrm{t}_{\text {tabel }}$ maka $\mathrm{H}_{\mathrm{o}}$ diterima, hal ini menunjukkan tidak adanya besaran pengaruh yang signifikan antara variabel X terhadap variabel Y.

\section{Uji f}

Dalam penelitian ini, uji f digunakan untuk mengetahui signifikansi pengaruh variabelindependen $(\mathrm{X})$ secarabersama-sama terhadap variabel dependen (Y). Langkahlangkah untuk melakukan pengujian adalah sebagai berikut:

a. Menentukan $\mathrm{H}_{\mathrm{o}}$ dan $\mathrm{H}_{1}$

$\mathrm{H}_{\mathrm{o}}: \mathrm{b}_{1}=\mathrm{b}_{2}=\mathrm{o}$; Tidak terdapat besaran pengaruh secara bersama-sama kepuasan komunikasi organisasi (X) terhadap kinerja pegawai $(\mathrm{Y})$.

Ha: $b_{1}=b_{2} \neq 0$; Terdapat besaran pengaruh secara bersama-sama kepuasan komunikasi organisasi (X) terhadap kinerja pegawai (y).

b. Menentukan level of significant $\alpha=5 \%$

c. Menghitung nilai $\mathrm{f}$

$\mathrm{F}_{\text {hitung }}=\frac{(\mathrm{SSR} / \mathrm{k})}{(\mathrm{SSE} /[\mathrm{n}-(\mathrm{k}+\mathbf{1})])}$

Dimana:

SSR = Keragaman regresi $($ SS Total SSE)

SSE $=$ Keragaman kesalahan

$\mathrm{n}=$ Jumlah variabel bebas

$\mathrm{k}$ = Jumlah sampel(Siregar, 2013)

d. Kriteria pengujian

$\mathrm{H}_{\mathrm{o}}$ diterima jika $\mathrm{f}_{\text {hitung }}<\mathrm{f}_{\text {tabel }}$

$\mathrm{H}_{\mathrm{o}}$ ditolak jika $\mathrm{f}_{\text {hitung }}>\mathrm{f}_{\text {tabel }}$

e. Kesimpulan

Untukmengetahui $\mathrm{H}_{\mathrm{o}}$ diterimaatauditolak dilakukan dengan cara membandingkan hasil perhitungan signifikansi dengan level of significant $=5 \%(0,05)$. Jika $\mathrm{f}_{\text {hitung }}>\mathrm{f}_{\text {tabel }}$ maka $\mathrm{H}_{\mathrm{o}}$ ditolak, hal ini menunjukkan bahwa secara signifikan variabel independen $(\mathrm{X})$ secara bersamasama mempengaruhi variabel dependen (Y). Sedangkan apabila $\mathrm{f}_{\text {hitung }}<\mathrm{f}_{\text {tabel }}$ maka $\mathrm{H}_{\mathrm{o}}$ diterima, hal ini menunjukkan bahwa secara signifikan variabel independen (X) tidak mempengaruhi variabel dependen (Y).

\section{Uji Koefisien Determinasi $\left(\mathbf{R}^{2}\right)$}

Dalam penelitian ini, uji koefisien determinasi digunakan untuk mengetahui sumbangan yang diberikan variabel bebas (X) terhadap variabel terikat (Y) yang ditunjukkan dalam prosentase. Rumus yang digunakan untuk menguji koefisien determinasi adalah sebagai berikut:

$$
\mathrm{R}^{2}=\underset{\mathrm{SST}}{\mathrm{SSR}} \text { atau } \mathrm{R}_{\text {adjusted }}^{2}=1-\left(1-\mathrm{R}^{2}\right) \frac{(\mathrm{n}-1)}{(\mathrm{n}-\mathrm{k})}
$$

Dimana:

$\begin{array}{ll}\text { SSR } & =\text { Keragaman regresi (SS Total- } \\ \text { SSE) } & \\ \text { SST } & =\text { Keragaman total } \\ \mathrm{n} & =\text { Jumlah sampel } \\ \mathrm{k} & =\text { Jumlahvariabelbebas(Sanusi, }\end{array}$
2012)

\section{HASIL DAN PEMBAHASAN}

Berdasarkan dari hasil uji validitas yang telah dilakukan dengan menggunakan program aplikasi SPSS 17.0, untuk variabel kepuasan komunikasi organisasi didapat bahwa sebanyak 19 item pernyataan dinyatakan valid, karena nilai $\mathrm{r}_{\text {hitung }}$ koefisien korelasi product moment lebih besar dari nilai $r_{\text {tabel }}$ sebesar 3,344. Dengan demikian, seluruh item pernyataan untuk variabel kepuasan komunikasi organisasi layak digunakan sebagai instrumen penelitian. Sebanyak 19 item pernyataan tersebut telah mewakili ketujuh indikator dari kepuasan komunikasi organisasi. Indikator pertama dan kedua terwakili oleh sebanyak 3 item pernyataan, indikator ketiga dan keempat terdiri dari 2 item pernyataan, indikator kelima terdapat 3 
item pernyataan, indikator keenam sebanyak 4 item pernyataan dan indikator ketujuh terdiri dari 2 item pernyataan.

Berdasarkan dari hasil uji validitas untuk variabel kinerja pegawai yang juga diolah dengan menggunakan program aplikasi SPSS 17.0 didapat bahwa sebanyak 16 item pernyataan dinyatakan valid, karena nilai $\mathrm{r}_{\text {hitung }}$ koefisien korelasi product moment lebih besar dari nilai $r_{\text {tabel }}$ sebesar 3,344. Maka dari itu, seluruh item pernyataan untuk variabel kinerja pegawai juga layak digunakan sebagai instrumen penelitian. Sebanyak 16 item pernyataan tersebut telah mewakili seluruh indikator dari kinerja pegawai. Indikator pertama terdiri dari 3 item pernyataan, indikator kedua terdiri atas 2 item pernyataan, indikator ketiga sebanyak 4 item pernyataan, indikator keempat terdiri dari 3 item pernyataan, indikator kelima terdapat 1 item pernyataan, dan indikator keenam sebanyak 3 item pernyataan. Dengan demikian, jumlah pernyataan yang dinyatakan valid sehingga dapat digunakan sebagai instrumen penelitian dalam penelitian ini berjumlah 35 item, 19 item mewakili variabel kepuasan komunikasi organisasi dan 16 item sisanya mewakili variabel kinerja pegawai.

Hasil pengujian reliabilitas pada variabel kepuasan komunikasi organisasi yang diolah dengan menggunakan program aplikasi SPSS 17.0 diperoleh nilai alpha cronbach lebih besar dari o,6o yaitu sebesar 0,937, hal ini menunjukkan bahwa tingkat reliabilitas tergolong baik. Hasil pengujian reliabilitas pada variabel kinerja pegawai diperoleh nilai alpha cronbach yang juga lebih besar dari o,6o yaitu sebesar 0,909, hal ini menunjukkan bahwa tingkat reliabilitas variabel kinerja pegawai juga tergolong baik. Berdasarkan dari hasil pengujian reliabilitas pada masing-masing variabel didapat nilai alpha cronbach lebih besar dari o,8o. Hal ini menjelaskan bahwa variabel kepuasan komunikasi organisasi sebesar o,937 dan kinerja pegawai sebesar 0,909 menunjukkan kuatnya reliabilitas dengan kategori sangat tinggi. Maka dari itu, dapat disimpulkan bahwa seluruh uji instrumen yaitu validitas dan reliabilitas telah memenuhi persyaratan untuk digunakan dalam melakukan penelitian.

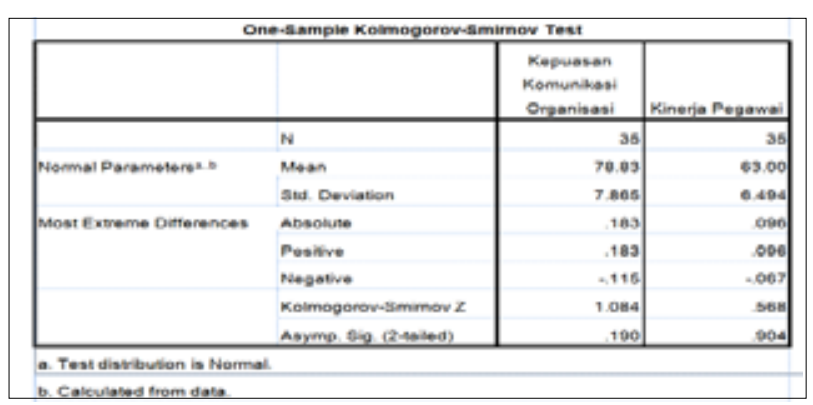

Gambar 1. Uji Normalitas

Gambar 1. di atas menunjukkan hasil uji normalitas yang telah dilakukan dengan menggunakan teknik uji Kolmogrov-Sminov yang diolah dengan menggunakan program aplikasi SPSS 17.0, didapati bahwa variabel kepuasan komunikasi organisasi memiliki nilai Asymp. Sig. (2-tailed) di atas $\alpha=0,05$ yaitu sebesar 0,190. Begitu juga dengan variabel kinerja pegawai yang memiliki nilai Asymp. Sig. (2-tailed) sebesar o,904. Hal ini menandakan bahwa kedua variabel tersebut, yaitu kepuasan komunikasi organisasi dan kinerja pegawai terdistribusi dengan normal. Hal ini menunjukkan bahwa dalam penelitian ini, pengujian hipotesis dengan tujuan untuk mengetahui adakah pengaruh kepuasan komunikasi organisasi terhadap kinerja pegawai di Sekretariat DPRD Kota Singkawang dapat dilakukan dengan menggunakan analisis regresi linear sederhana.

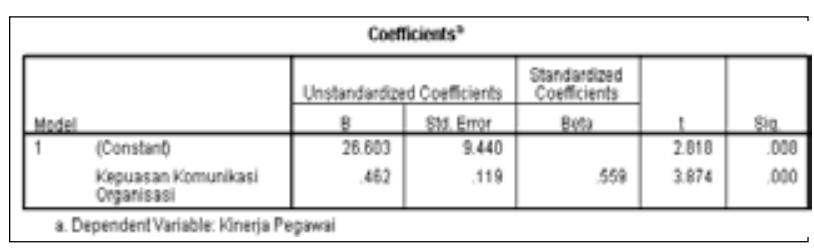

Gambar 2. Uji Regresi Linear Sederhana dan Uji t

Berdasarkan dari hasil uji di atas yang diolah menggunakan SPSS 17.0, dapat dibentuk sebuah persamaan linear regresi sederhana. Pada hasil uji regresi linear sederhana di atas, didapat nilai konstanta sebesar 26,603 dan nilai koefisien regresi sebesar 0,462. Sehingga menghasilkan 
bentuk persamaan linear regresi sederhana $\mathrm{Y}=26,603+0,462 \mathrm{X}$. Dari persamaan tersebut didapat nilai konstan dari regresi variabel kinerja pegawai sebesar 26,603. Sedangkan koefisien regresi dari variabel kepuasan komunikasi organisasi yang bernilai positif yaitu sebesar 0,462. Hal ini berarti variabel kepuasan komunikasi organisasi mempunyai pengaruh yang positif terhadap variabel kinerjapegawaisebesaro,462. Setiapkenaikan satu satuan variabel kepuasan komunikasi organisasi akan menaikkan nilai variabel kinerja pegawai sebesar o,462. Berdasarkan dari hasil pengujian tersebut, dapat diartikan bahwa semakin tinggi kepuasan komunikasi organisasi seorang pegawai, maka akan semakin baik pula kinerja yang dihasilkan oleh pegawai tersebut.

Selain menunjukkan hasil uji regresi linear sederhana, gambar 1 . di atas juga menunjukkan hasil dari pengujian hipotesis dengan menggunakan uji t. Berdasarkan dari hasil uji di atas, nilai $\mathrm{t}$ yang didapat sebesar 3,874 dengan nilai signifikansi sebesar o,ooo. Untuk menguji hipotesis dapat dilakukan dengan dua cara.Pertama dapat dilakukan dengan membandingkan nilai t. Kedua, dapat dilakukan dengan cara melihat nilai signifikansi. Dalam jurnal ini, peneliti menggunakan cara pertama untuk melakukan uji hipotesis, yaitu dengan membandingkan nilai $t_{\text {hitung }}$ dengan nilai $\mathrm{t}_{\text {tabel. }}$ Berdasarkan dari uji t di atas, didapat nilai t sebesar 3,874 lebih besar dari nilai $\mathrm{t}_{\text {tabel }}$ yaitu sebesar 2,034. Maka dari itu, dapat disimpulkan bahwa $\mathrm{H}_{\mathrm{o}}$ ditolak Ha diterima. Hal ini menunjukkan bahwa adanya besaran pengaruh yang signifikan antara variabel kepuasan komunikasi organisasi (X) terhadap variabel kinerja pegawai (Y).

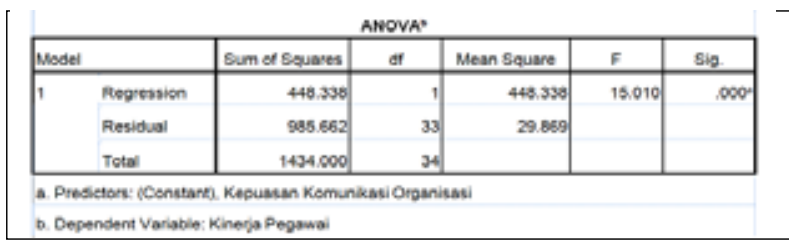

Gambar 3. Uji F (ANOVA)

Dari hasil uji ANOVA atau uji F di atas yang juga dilakukan dengan menggunakan programaplikasi SPSS 17.o, didapat nilai $\mathrm{F}_{\text {hitung }}$ sebesar 15,010 lebih besar dari nilai $\mathrm{F}_{\text {tabel }}$ yaitu sebesar 4,14 dengan nilai signifikansi jauh lebih kecil dari $\alpha=0,05$ yaitu o,ooo. Maka dari itu, dapat disimpulkan bahwa $\mathrm{H}_{\mathrm{o}}$ ditolak $\mathrm{Ha}$ diterima. Hal ini menunjukkan bahwa secara signifikan variabel independen (kepuasan komunikasi organisasi) secara bersamasama mempengaruhi variabel dependen (kinerja pegawai). Nilai signifikansi yang lebih kecil dari 0,05 yaitu sebesar 0,000 menandakan bahwa model regresi adalah linear. Berdasarkan hal tersebut, dapat dikatakan bahwa tingginya kepuasan komunikasi organisasi yang dirasakan oleh para pegawai akan berpengaruh positif terhadap kinerja pegawai yang dihasilkan. Begitu pula sebaliknya, rendahnya rasa kepuasan komunikasi organisasi para pegawai akan berpengaruh negatif terhadap kinerja pegawai tersebut.

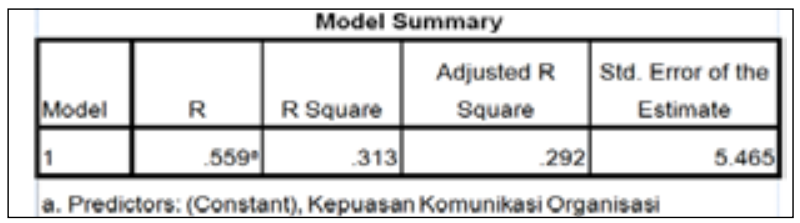

Gambar 4. Uji Koefisien Determinasi $\left(\mathrm{R}^{2}\right)$

Selain melakukan pengujian dengan menggunakan uji $t$ dan uji f, untuk memperkuat analisis penulis juga melakukan uji koefisien determinasi $\left(\mathrm{R}^{2}\right)$. Gambar 3 . di atas menunjukkan hasil dari uji $\mathrm{R}^{2}$ yang dilakukan dengan menggunakan program aplikasi SPSS 17.o. Berdasarkan dari hasil uji koefisien determinasi yang dilakukan, didapat bahwa koefisien korelasi (R) memiliki nilai sebesar o,559 dan nilai koefisien determinasi $\left(\mathrm{R}^{2}\right)$ yang diperoleh sebesar o,313. Hal ini menunjukkan bahwa, sumbangan pengaruh yang diberikan oleh variabel kepuasan komunikasi organisasi terhadap kinerja pegawai adalah sebesar $31,3 \%$ sedangkan $68,7 \%$ sisanya dipengaruhi oleh variabel lain.

Hasil dari penelitian ini menunjukkan bahwa adanya besaran pengaruh kepuasan komunikasi organisasi terhadap kinerja pegawai di Sekretariat Dewan Perwakilan Rakyat Daerah (DPRD) Kota Singkawang. 
Meskipun besaran pengaruh yang ditimbulkan kurang maksimal, yaitu hanya sebesar $31,3 \%$. Indikator dari kepuasan komunikasi organisasi yang paling tinggi dirasakan oleh para pegawai di Sekretariat DPRD Kota Singkawang adalah kepuasan terhadap kualitas media. Sebanyak $74,2 \%$ pegawai di Sekretariat DPRD Kota Singkawang menyatakan bahwa informasi yang disampaikan instansi kepada mereka sangat bermanfaat dan sudah cukup memuaskan. Para pegawai menyatakan bahwa mereka merasa sudah cukup puas terhadap segala informasi yang mereka terima dari instansi.

Hasil ini berbanding terbalik dengan hasil penelitian yang pernah dilakukan sebelumnya oleh Zulhamri Abdullah dan Jong Huidalam jurnalnya yang berjudul "The Relationship between Communication Satisfaction and Teachers' Job Satisfaction in the Malaysian Primary School". Hasil analisis menunjukkan bahwa kualitas media secara signifikan tidak memberikan sumbangan pengaruh terhadap kepuasan kerja para guru di Sekolah Dasar di Malaysia. Meskipun terdapat hubungan yang positif antara kualitas media dengan kepuasan kerja, namun berdasarkan dari hasil analisis didapati bahwa nilai signifikansi kualitas media lebih besar dari o,05 yaitu sebesar o,164. Hal ini menandakan bahwa tidak terdapat hubungan yang signifikan antara kepuasan terhadap kualitas media dengan kepuasan kerja yang dirasakan oleh para guru di Sekolah Dasar di Malaysia (Abdullah \& Hui, 2014).

Selain puas terhadap kualitas media, sebanyak 45,7\%pegawai di Sekretariat DPRD Kota Singkawang juga menyatakan bahwa mereka merasa sangat puas terhadap hubungan baik yang selama ini mereka bina dengan seluruh rekan kerja yang ada di Sekretariat DPRD Kota Singkawang. Sebagian besar para pegawai menyatakan bahwa mereka berusaha untuk selalu menjaga hubungan baik dengan seluruh rekan kerja yang ada di Sekretariat DPRD Kota Singkawang.Kepuasan yang dirasakan oleh para pegawai di Sekretariat DPRD Kota Singkawang terhadap cara komunikas teman sekerja mereka berdampak pada salah satu indikator dari kinerja pegawai, yaitu pada indikatordampakantarpribadi (interpersonal impact).

Didapati bahwa sebanyak 77,1\%pegawai di Sekretariat DPRD Kota Singkawang menyatakan bahwa mereka tidak merasa kesulitan bila harus bekerja sama dengan rekan kerja dari divisi atau bagian yang berbeda. Sebanyak 31,4\% pegawai di instansi tersebut menyatakan bahwa mereka cukup mampuuntukmembangunsebuah kerjasama serta hubungan yang baik dengan seluruh pegawai yang ada di instansi tersebut. Tidak sedikit dari mereka yang merasa cukup puas terhadap kerja sama serta hubungan yang mereka jalin dengan seluruh pegawai yang ada di Sekretariat DPRD Kota Singkawang.

Hal ini sejalan dengan penelitian yang pernah dilakukan sebelumnya yang mengatakan bahwa komunikasi organisasi juga bertujuan untuk meningkatkan semangat kinerja karyawan. Menumbuhkan sikap kedisiplinan, menambah kekompakan, dan merasa senang untuk bekerja (Sari, 2012). Jika para pegawai merasa tidak puas atau tidak bahagia terhadap instansi atau organisasi, maka ada kemungkinan bahwa efektivitas organisasi atau instansi secara keseluruhan berada dalam kondisi yang tidak baik (Ogunjinmi, Ladebo, Onadeko, \& Ogunjinmi, 2013). Maka dari itu, untuk dapat meningkatkan kepuasan komunikasi organisasi serta kinerja pegawai yang tinggi, diperlukan adanya kerja sama antar kedua belah pihak, yaitu antara pihak Sekretariat DPRD Kota Singkawang dan para pegawai yang ada di instansi tersebut, agar senantiasa memperhatikan segala aspek komunikasi serta keharmonisan hubungan yang terdapat di dalam instansi, sehingga dapat meningkatkan kinerja para pegawai.

Penelitian ini menunjukkan bahwa kepuasan komunikasi organisasi bukan merupakan satu-satunya faktoryang mempengaruhi kinerja pegawai di Sekretariat DPRD Kota Singkawang. Karena berdasar dari hasil uji koefisien determinasi yang dilakukan, didapat bahwa koefisien korelasi (R)memiliki nilai sebesar 0,559 dan nilai koefisien 
determinasi $\left(\mathrm{R}^{2}\right)$ yang diperoleh sebesar 0,313 . Hal ini menunjukkan bahwa, pengaruh yang diberikan oleh variabel kepuasan komunikasi organisasi terhadap kinerja pegawai hanya sebesar $31,3 \%$ sedangkan sebesar $68,7 \%$ sisanya dipengaruhi oleh variabel lain seperti salah satunya bisa berupa iklim komunikasi organisasi. Sejalan dengan hasil penelitian yang pernah dilakukan sebelumnya oleh Mar'atus Sholichah dalam jurnalnya yang berjudul "Pengaruh Iklim Komunikasi Organisasi Terhadap Kinerja Pegawai (Survey Pada Bagian Humas Pemerintah Provinsi DIY), didapati bahwa iklim komunikasi juga memberikan sumbangan pengaruh terhadap kinerja pegawai pada bagian Humas Pemerintah Provinsi DIY, meskipun besaran pengaruh yang diberikan berada dalam kategori rendah yaitu sebesar 14,3\%(Sholichah, 2012).

\section{SIMPULAN}

Dari keseluruh hasil pembahasan di atas, dapat disimpulkan bahwa $\mathrm{H}_{\mathrm{o}}$ ditolak dan $\mathrm{Ha}$ diterima. Dengan kata lain, terdapat besaran pengaruh positif yang signifikan antara kepuasan komunikasi organisasi terhadap kinerja pegawai di Sekretariat DPRD Kota Singkawang. Hal ini sejalan dengan hasil penelitian yang pernah dilakukan sebelumnya oleh Yani Tri Wijayanti, Asep Suryana, Mien Hidayat, dan Funny Mustikasari pada tahun 2015 yang meneliti tentang pengaruh kepuasan komunikasi terhadap kinerja para pendidik Institut Pemerintahan Dalam Negeri (IPDN)di Jatinangor.

Hasil penelitian tersebut menyatakan bahwa terdapat pengaruh variabel kepuasan komunikasi terhadap kinerja pendidik IPDN Jatinangor, namun sumbangan pengaruh yang diberikan oleh kepuasan komunikasi terhadap kinerja pendidik IPDN Jatinangor sangat kecil, hanya sebesar 9\% sedangkan 91\% lainnya dipengaruhi oleh faktor lain. Tidak seperti di Sekretariat DPRD Kota Singkawang, kepuasan komunikasiorganisasi memberikan sumbangan pengaruh sebesar $31,3 \%$ terhadap kinerja para pegawainya.
Jika diurutkan berdasarkan besarnya kepuasan komunikasi organisasi yang dirasakan oleh para pegawai di Sekretariat DPRD Kota Singkawang, indikator efisiensi berbagai macam saluran komunikasi menempati urutan terakhir. Hal ini menandakan bahwa para pegawai di Sekretariat DPRD Kota Singkawang merasa kurang puas terhadap cara instansi tersebut menyebarluaskan informasi. Sejalan dengan hal ini, para tenaga pendidik di IPDN Jatinangor juga merasa kurang puas terhadap efisiensi berbagai macam saluran komunikasi di instansi tersebut.

Sebanyak $11,4 \%$ pegawai di Sekretariat DPRD Kota Singkawang menyatakan bahwa cara instansi menyebarluaskan informasi kurang efektif dan informasinya tidak tersebar secara merata. Kepuasan komunikasi sangat berpengaruh terhadap keterlibatan pegawai dalam sebuah instansi. Kepuasan para pegawai berhubungan dengan hasil yang akan diperoleh atau dicapai oleh sebuah instansi, maka dari itu hal ini sangat penting untuk diperhatikan oleh instansi atau organisasi agar dapat tercapainya visi dan misi dari instansi tersebut(Jaupi \& Llaci, 2015).

Hasil dari penelitian ini diharapkan mampu memberikan masukan dan manfaat kepada pihak Sekretariat DPRD Kota Singkawang. Agar senantiasa memperhatikan aspek kepuasan komunikasi organisasi para pegawainya, sehingga dapat berpengaruh positif terhadap kinerja mereka. Sebagai salah satu upaya instansi untuk mewujudkan visi dan misi, diperlukan hubungan komunikasi yang terjalin harmonis antar seluruh anggota instansi serta sumber daya manusia yang berkualitas, sehingga kinerja yang maksimal dari para pegawai serta komunikasi organisasi yang efektif sangat diperlukan. 


\section{DAFTAR PUSTAKA}

Abdullah, Z., \& Hui, J. 2014. No TitleAbdullah, Z., \& Hui, J. 2014. No Title. The Relationship between Communication Satisfaction and Teacher's Job Satisfaction in the Malaysian Primary Shcool, 2(2). The Relationship between Communication Satisfaction and Teacher's Job Satisfaction in the Malaysian Primary Shcool, 2(2).

Alsayed, A. K., Motaghi, M. H., \& Osman, I. B. 2012. No Title. The Relationship between Communication Satisfaction and Performance Indicators in Palestinian Governmental Organization, 2(11).

Arikunto, S. 2006. Prosedur Penelitian Pendekatan Praktik. Jakarta: Rineka Cipta.

CH. (n.d.). Ya Allah.! Anggota DPRD Singkawang Belum Dapat Emblem. Retrieved January 1, 2015, from http:// beritakalimantan.co/ya-allah-anggotadprd-singkawang-belum-dapatemblem/

Fahmi, I. 2013. Perilaku Organisasi Teori, Aplikasi, dan Kasus. (M. Djalil, Ed.). Bandung: Alfabeta.

Jaupi, F., \& Llaci, S. 2015. No Title. The Impact of Communication Satisfaction and Demographic Variables on Employee Engagement.

Kosasih, D. E., \& Susanto, S. S. D. 2014. "Komunikasi Organisasi Dalam Pengembangan Kinerja Pengurus Gapoktan Pada Program Penguatan Lembaga Distribusi Pangan Masyarakat (Kasus Pada Gapoktan di Kabupaten Subang dan Kabupaten Bogor)”, 12(2).

Kriyantono, R. 2006. Teknik Praktis Riset Komunikasi (pertama). Jakarta: Kencana Prenada Media Group.

Manopo, J. V. 2014. "Peran komunikasi organisasi dalam membentuk efektivitas kerja karyawan cv . Magnum
Sign and Print Advertising Samarinda", 2(3), 357-372.

Masmuh, A. 20o8. Komunikasi Organisasi Dalam Perspektif Teori Dan Praktek. Malang: UPT Penerbitan Universitas Muhammadiyah Malang.

Morissan. 2012. Metode Penelitian Survey (Pertama). Jakarta: Kencana Prenada Media Group.

Ogunjinmi, A. A., Ladebo, O. J., Onadeko, S. A., \& Ogunjinmi, O. K. (2013). No Title. Demographic and Professional Factors as Predictors of Communication Satisfaction among Nigeria National Park's Employees, 9.

Peraturan Walikota Singkawang Nomor 6o Tahun 2009 Tentang Uraian Tugas Pejabat Struktural Di Lingkungan Sekretariat DPRD Kota singkawang.

Rajhans, K. 2012. No Title. Effective Organizational Communication a Key to Employee Motivation and Performance, 2(2).

Rencana Strategis (RENSTRA) Sekretariat DPRD Kota Singkawang Tahun 20132017.

Ruliana, P. 2014. Komunikasi Organisasi Teori Dan Studi Kasus. Jakarta: PT RajaGrafindo Persada.

Sanusi, A. 2012. Metodologi Penelitian Bisnis. Jakarta: Salemba Empat.

Sari, T. D. M. 2012. "Peran Komunikasi Organisasi Terhadap Kinerja Karyawan (Studi Deskriptif Kualitatif Terhadap Peran Komunikasi Organisasi Terhadap Kinerja Karyawan RT. Ortopedi Prof. Dr. R. Soeharso Surakarta)".

Sholichah, M. 2012. Pengaruh Iklim Komunikasi Organisasi terhadap Kinerja Pegawai (Survey pada Bagian Humas Pemerintah Provinsi DIY).

Siregar, S. 2013. Metode Penelitian Kuantitatif Dilengkapi Dengan Perbandingan Perhitungan Manual \& SPSS. Metode Penelitian Kuantitatif Dilengkapi Dengan Perbandingan Perhitungan 
Manual \& SPSS (Pertama). Jakarta: Kencana Prenada Media Group.

Sugiyono. 2015. Metode Penelitian $\mathcal{E}$ Pengembangan. Bandung: Alfabeta.

Tri, W. Y., Asep, S., \& dkk. 2015. KINERJA PENDIDIK IPDN JATINANGOR, 9April 2015, 153-170.

Umam, K. 2010. Perilaku Organisasi. Bandung: CV.Pustaka Setia.

Wayne Pace, R., \& Faules, D. F. 2013. Komunikasi Organisasi Strategi Meningkatkan Kinerja Perusahaan. (D. Mulyana, Ed.). Bandung: PT Remaja Rosdakarya. 